\title{
Effects of Malathion on Cellularity and Sperm Differentiation in Testis and Epididymis of Adult Rats
}

\author{
Efectos del Malatión en la Celularidad y Diferenciación de \\ Espermatozoides en Testículo y Epidídimo de Ratas Adultas
}

Espinoza-Navarro, O.* \& Bustos-Obregón, E.**

ESPINOZA-NAVARRO, O. \& BUSTOS-OBREGÓN, E. Effects of malathion on cellularity and sperm differentiation in testis and epididymis of adult rats. Int. J. Morphol., 32(1):119-124, 2014.

SUMMARY: Malathion is an organophosphorous insecticide, used worldwide for pest and disease control; however, it could also affect the reproductive patterns of several species. The aim of this study was to determine the effects of malathion in the cellularity and sperm differentiation in testis and epididymis of rats. Twenty adult male Sprague Dawley rats were divided into a malathion-treated group ( $\mathrm{n}=10$, dose of $170 \mathrm{mg} / \mathrm{kg}$ via subcutaneous injection for a period of 13 days) and control group ( $\mathrm{n}=10$, injected only with normal saline). After treatments, the rats were sacrificed by regulated euthanasia and assessed for sperm count in testis and epididymis and epididymal teratospermia degree. The results showed a significant decrease in body, testicular and epididymal weight in animals treated with malathion. Testicular sperm counts in treated rats exhibited a significant decrease in the number of sperm compared to controls $\left(42.56 \times 10^{6}\right.$ vs. $\left.95.99 \times 10^{6}\right)$, as well as in epididymis $\left(77.55 \times 10^{6}\right.$ vs. $\left.106.54 \times 10^{6}\right)$. Concerning the degree of teratospermia, a significant increase of abnormal sperm in the epididymis of treated rats versus controls ( $42.1 \%$ vs. $21 \%$, respectively) was observed. We conclude that malathion has a cytotoxic effect in rats, significantly reducing the number of sperm produced by the seminiferous tubules and affecting their quality and number during the process of maturation and capacitation in their transit through the epididymis, thus increasing the level of teratospermia.

KEY WORDS: Reproduction; Rat; Malathion; Cytotoxicity.

\section{INTRODUCTION}

The environment is increasingly being influenced by the presence of waste and subproducts of natural and anthropogenic origin. Anthropogenic pollution is evidenced in a large number of chemicals, such as drugs, food additives or pesticides, which would be largely responsible for damage and alterations at morphological and genetic levels in several species (ATSDR, 2000; Bustos-Obregon \& Hartley, 2008).

Organophosphate insecticides are the most used worldwide for the fumigation of plants and crops. This type of pesticide acts by inhibiting the enzyme acetylcholinesterase, which prevents nerve impulses that travel to muscles through cholinergic fibers of the autonomic nervous system are activated permanently. Inhibition of this enzyme results in accumulation of acetylcholine, responsible for the clinical manifestations of poisoning in animals and humans (Bello-Ramirez et al., 2000; Kwong, 2002; Joshi \& Sharma, 2011).

Malathion is an organophosphate chemical compound whose chemical formula is 0,0-dimethyl-S-(1,2-dicarbetoxyethyl)- phosphorus dithioate (Fig. 1). It is considered to have low toxicity to mammals and has been widely used in public health. It is employed as a systemic pesticide with action by contact and ingestion to control insects in foliage and soils (EPA, 2012). It is absorbed via the respiratory or digestive tract and skin; in humans, it can provoke death by respiratory failure since the increase in the concentration of acetylcholine blocks neuromuscular transmission. The lethal dose of malathion for an adult man is estimated at $24 \mathrm{mg}$ per kilogram of weight. In rats, the LD50 via intraperitoneal (ip) exposure is $750 \mathrm{mg} / \mathrm{kg}$ body weight (Kwong).

\footnotetext{
* Faculty of Sciences, Department of Biology, Universidad de Tarapacá, Arica, Chile.

${ }^{* *}$ Faculty of Medicine, ICBM, Universidad de Chile, Santiago, Chile.
} 
The aim of this study was to determine the effects of the organophosphorous insecticide malathion in the cellularity and the differentiation of sperm cells in the testis and epididymis of rats.

\section{MATERIAL AND METHOD}

Two month-old male Sprague Dawley rats, with average weight of $250 \mathrm{~g}$, were selected for this research (Blazak et al., 1985). Ten individuals were treated with daily subcutaneous (sc) doses of malathion of $170 \mathrm{mg} / \mathrm{kg}(1 / 4$ LD50) for a period of 13 days, which corresponds to the cycle of the seminiferous epithelium of rat. Control animals $(n=10)$ received only saline under the same protocol. Both experimental groups were kept separated, with access to food and water ad libitum. The protocols for the experimental work with animals were approved by the Ethics/Bioethics Committee of the University of Tarapacá.

At the end of treatment, the animals were ethically euthanized and surgical removal and weigh of testes and epididymis were performed. Sperm were obtained by mincing the proper organ in $5 \mathrm{~mL}$ PBS, $\mathrm{pH} 7.4$, filtered on double gauze and allowed to stand for 24 hours. Tissue homogenates were finally performed at $100 \mathrm{rpm}$ for 30 seconds. Sperm counts from testis and epididymis were performed in a Neubauer hemocytometer chamber, expressing the sperm number per milligram of tissue.
Teratospermia levels were assessed only in epididymal sperm. A 200-microliter sperm suspension was incubated for 10 minutes in $1 \mathrm{~mL}$ of $0.8 \mathrm{M}$ sodium thioglycolate, $\mathrm{pH} 9.0$ (reducing agent) for better evidence of the phenomenon of chromatin decondensation (BustosObregon \& Hartley. Sperm smears were stained with hematoxylin/eosin, mounted with Histamount ${ }^{\circledR}$ and observed under light microscopy at 1000X magnification. Four fields were analyzed and 250 spermatozoa were counted per field. The results were expressed as percentage of abnormal sperm per milligram of epididymal tissue. Sperm cells considered as abnormal or teratospermic were swollen head sperm -typical of chromatin decondensation- and sperm with tail damage or lacking a flagellum -assuming a deleterious action of malathion on the sperm neck region.

Data are presented as Mean \pm SD and Student's t test was performed for statistical analysis of results. Values with $\mathrm{p}<0.05$ were considered significant.

\section{RESULTS}

Table I shows the results of initial and final body weight, exhibiting a significant decrease in the final weights of treated rats. Also, a significant decrease in weight and testicular sperm count in treated rats was evidenced $(\mathrm{p}<0.05)$.

Table II shows a significant decrease in weight and

Table I. Results of body and testicular weight and sperm count in groups of male rats $(\mathrm{n}=10)$ treated with $170 \mathrm{mg}$ malathion $/ \mathrm{kg}$ body weight via subcutaneous (sc) injection during 13 days versus controls with saline

\begin{tabular}{lcc}
\hline & Control & Treated with malathion \\
\cline { 2 - 3 } Initial body weight $(\mathrm{g})$ & $276 \pm 11.4$ & $273 \pm 9,2$ \\
Final body weight $(\mathrm{g})$ & $384 \pm 14.3$ & $342 \pm 16^{*}$ \\
Testicular weight $(\mathrm{g})$ & $3.62 \pm 0.08$ & $2.68 \pm 0.05^{*}$ \\
Sperm count $(\mathrm{x} 106)$ & $95.99 \pm 17.5$ & $42.56 \pm 16.9^{*}$ \\
\hline (Mean $\left.\pm \mathrm{SD},{ }^{*} \mathrm{p}<0.05\right)$. & &
\end{tabular}

Table II. Results of total epididymal weight, sperm counts and teratospermia in groups of male rats $(\mathrm{n}=10)$ treated with $170 \mathrm{mg}$ malathion/ $\mathrm{kg}$ body weight via subcutaneous (sc) injection during 13 days versus controls with saline

\begin{tabular}{lcc}
\hline & Control & Treated with malathion \\
\cline { 2 - 3 } Total epididymal weight $(\mathrm{mg})$ & $410 \pm 0.1$ & $305 \pm 0.4^{*}$ \\
Sperm count & & \\
$\quad$ Total epididymis (106) & $106.543 \pm 9.17$ & $77.548 \pm 8.72^{*}$ \\
$\quad$ Total teratospermia (\%) & $21.0 \pm 5.12$ & $42.1 \pm 6.48^{*}$ \\
Teratos permic types & & \\
$\quad$ Sperm head & $14.3 \pm 6.8$ & $26.4 \pm 5.2^{*}$ \\
$\quad$ Sperm tail & $7.7 \pm 3.1$ & $13.6 \pm 4.3$ \\
\hline
\end{tabular}

(Mean \pm SD, *p<0.05). 


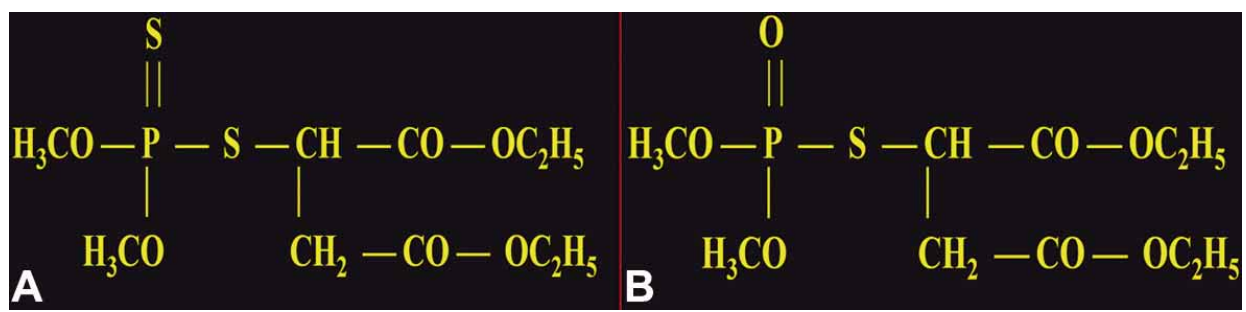

Fig. 1. Chemical structure of malathion (A) and your metabolite malaoxon (B).

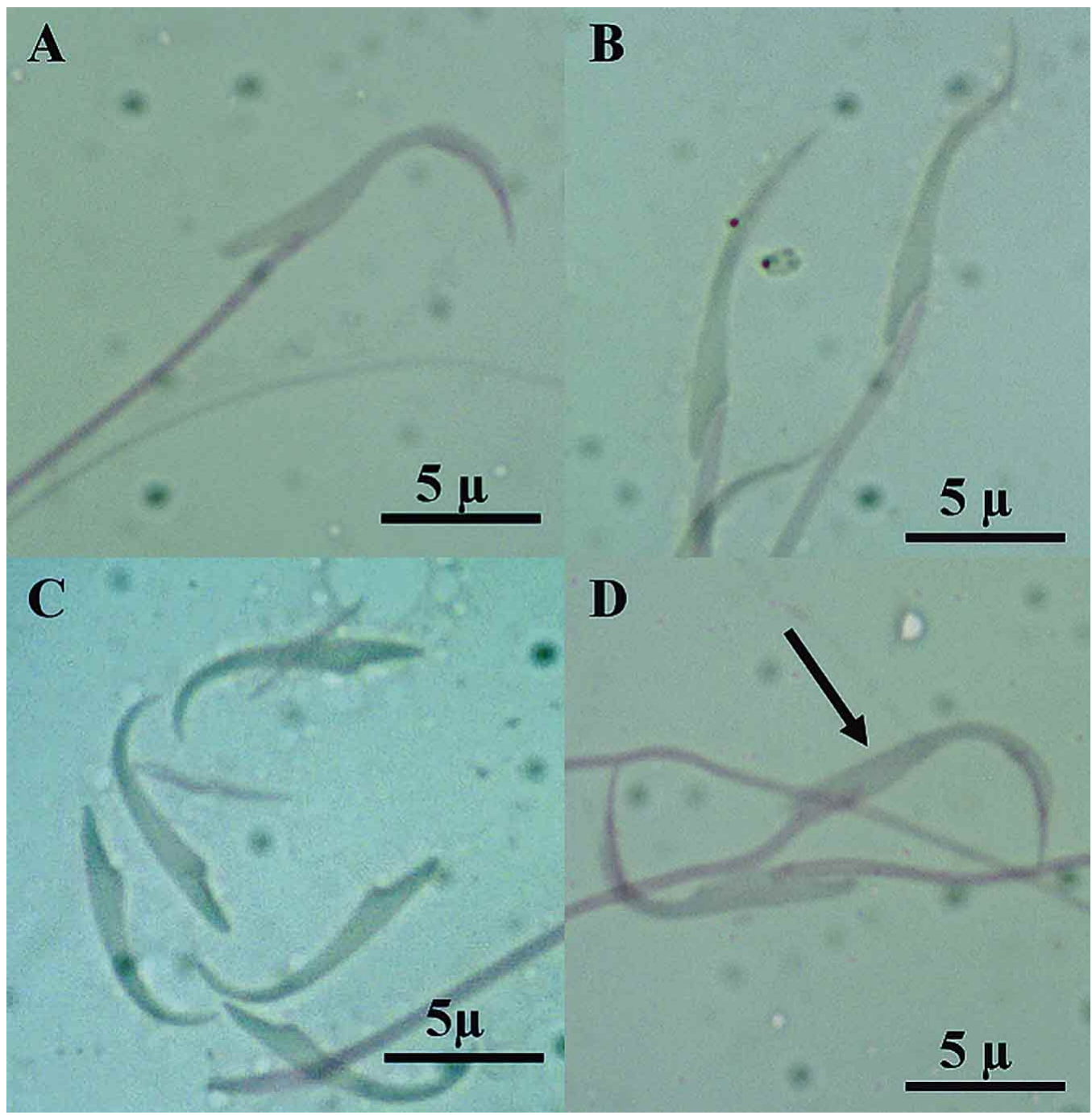

Fig. 2. The microphotographs show normal sperm from control rats (A), sperm head abnormalities (B) and loose sperm heads from treated rats (C). In (D), a sperm treated with malathion and subsequent treatment with sodium thioglycolate with decondensed nuclear region is shown (arrow).

epididymal sperm count of rats treated with malathion. The teratospermia level showed a significant increase in treated rats $(42.1 \%)$, with high levels of abnormal sperm heads $(26.4 \%)(\mathrm{p}<0.05)$.

Figure 2 shows images of normal sperm cells in con- trol rats $(2 \mathrm{~A})$. Figure $2 \mathrm{~B}$ shows the abnormalities observed in sperm heads from treated rats. In $2 \mathrm{C}$, there is a large amount of sperm heads lacking a flagellum from treated rats. In $2 \mathrm{D}$, a sperm treated with malathion and sodium thioglycolate is shown, displaying chromatin recondensation in the area of the sperm nucleus. 


\section{DISCUSSION}

Malathion, an organophosphorous pesticide (OP), is activated in the liver by oxidative and hydrolytic enzymes, replacing the sulfur for oxygen, thus originating the active principle malaoxon (Fig. 1). Malathion is reported to be a mutagenic agent capable of inducing DNA breaks or altering its spatial organization by interacting with DNA-associated proteins (Lu et al., 2012).

The induction of sperm failures in animals treated with chemical agents is considered an excellent in vivo model to assess the degree of toxicity of pollutants, since the sperm shape is characteristic of every species. Spermatogenesis in the mammalian testis is the sum of several processes that end up in the adult with the production of sperm, which are released from the male germinal epithelium during spermiation into the epididymis where they suffer other morphological and physiological changes, such as migration of the cytoplasmic droplet, modification of the acrosome, sperm motility and increased chromatin packaging. All these processes finally allow the sperm maturity that capacitates them for fertilization. Any factor that affects sperm production in the testis or in the epididymis will necessarily affect the number and shape of the sperm cells (Joshi \& Sharma; Okamura et al., 2009).

Malathion, an organophosphate pesticide widely used in agriculture, exerts a proven lethal effect on many living systems; however, little is known about its chronic and sublethal effects on the reproduction and genetic material of species (Espinoza-Navarro \& Bustos-Obregon, 2005; El-Mazoudy \& Attia, 2012).

Occupational exposure to organophosphates may occur mainly by accidental inhalation and dermal absorption or as a result of improper handling. These pesticides occupy the second place in percentage of occupational poisoning with signs or symptoms that could result in dead. The Environmental Protection Agency (EPA) is currently warning about another organophosphate, azinphos-methyl (AZM), a pesticide that must be phased out since 2013 (Yucra et al., 2006; Hossain et al., 2010; EPA).

Our results show a significant loss of body weight in all rats treated with malathion (Table I), a finding that other authors using different animal models associate with an excessive secretion of body fluids that alters the balance of $\mathrm{Ca}++$ and $\mathrm{K}+$, which is reported as responsible for the changes in behavior and activity of the treated or intoxicated individuals with these organophosphate (Espinoza-Navarro \& Bustos-Obregon; Kalipci et al.,
2010). This diminution in body weight is also expressed in a significant decrease in the testicular weight of the treated rats; similar results have been reported by PennaVideau et al. (2012) in mice treated with malathion.

The significant decrease in sperm count, which is observed in testis and epididymis (Tables I and II), is possibly indicating that malathion, similar to other organophosphates, has been biodegraded and its metabolite malaoxon might be altering the cell cycle patterns in the germ line of the seminiferous tubules in testes and the biochemical cycles of the epididymal epithelium, decreasing the levels of sperm capacitation and maturation in rats treated with malathion, with a total impact on the reproductive patterns of male rats (Contreras et al., 2006; Narayana et al., 2006; Jorsaraei et al., 2010; Mathur \& D`Cruz, 2011).

The results observed in Table II and Figure 2 showed a significant increase in teratospermia levels in epididymis from treated rats to compare with control rats $(42.1 \% / 21 \%$ respectively). The alteration is significantly higher in abnormal sperm head, $26.4 \%$ in treated rat and $21 \%$ in control rats. These results were magnified by incubating the sperm with sodium thioglycolate as reducing agent, decondensating the sperm nuclear chromatin and thus increasing teratospermia. These results would indicate that malathion might be acting on the DNA-histones complex. In control rats, the chromatin integrity is ensured by intact disulfide bonds, which is evidenced in a large condensation and packaging of chromatin (Evenson et al., 2002).

In sperm, the alkylating properties of organophosphates also affect the assembly of flagellar protein; this would explain the high percentage of sperm heads lacking a flagellum, and thus altering their motility and their fertilizing ability (Akbarsha et al., 2000; Chapman \& Michael, 2003; Okamura et al.).

\section{CONCLUSION}

Malathion causes a significant decrease in body, epididymal and testicular weight in male rats. Exposure to the pesticide induces a significant decrease of sperm count, possibly by the action of its metabolite malaoxon, thus altering the patterns in the germinal epithelium of the seminiferous tubules of the testis and biochemical processes of sperm capacitation and maturation during epididymal transit.

Malathion significantly increases the levels of teratospermia, possibly through a direct effect of the 
compound or via a biochemical alteration that destabilizes the chromatin packaging in treated sperm, further altering the assembly of flagellar proteins during epididymal transit, and thus indicating that malathion have a cytotoxic effect on the reproductive patterns of male rats.

\section{ACKNOWLEDGMENTS}

This research was supported by University of Tarapacá through Major Project UTA 4712-13.

ESPINOZA-NAVARRO, O. \& BUSTOS-OBREGÓN, E. Efectos de malatión en la celularidad y diferenciación de espermatozoides en testículo y epidídimo de ratas adultas. Int. J. Morphol., 32(1):119-126, 2014.

RESUMEN: El malatión es un insecticida organofosforado, ampliamente usado en el control de plagas y pestes, sin embargo también puede afectar a los patrones reproductivos de las especies. El objetivo de este trabajo fue determinar los efectos de malatión en la celularidad y diferenciación de espermatozoides en testículo y en epidídimo de ratas. Veinte ratas macho adultas de la cepa Sprague Dawley, fueron divididos en grupo tratado con malatión $(\mathrm{n}=10)$ en dosis de $170 \mathrm{mg} / \mathrm{kg}$ de peso, inyección sub cutánea (s.c.), por un período de 13 días (duración del ciclo del epitelio seminífero) y grupo control $(n=10)$, los cuales solo fueron inyectados con suero fisiológico. Finalizado el tratamiento las ratas fueron sacrificadas por eutanasia normada y se procedió a medir el recuento espermático en testículo y epidídimo y el grado de teratospermia en epidídimo. Los resultados obtenidos muestran una disminución significativa en el peso corporal, testicular y del epidídimo de ratas machos tratados con malatión. El recuento espermático en testículo de ratas tratadas, al compararlos con ratas controles, muestra una disminución significativa en el número de espermatozoides $\left(42,56 \times 10^{6} / 95,99 \times 10^{6}\right)$, igual comportamiento se observó en epidídimo $\left(77,55 \times 10^{6} / 106,54 \times 10^{6}\right)$. Al determinar el grado de teratospermia se observó un aumento significativo de espermatozoides anormales, en el epidídimo de las ratas tratadas versus los controles $(42,1 \%$ y $21 \%$, respectivamente). Se concluye que malatión tiene un efecto citotóxico en ratas, disminuyendo significativamente el número de espermatozoides producidos por los túbulos seminíferos y afectando la calidad y el número de ellos durante el proceso de maduración y capacitación, en su tránsito por el epidídimo, aumentando el nivel de teratospermia.

PALABRAS CLAVE: Reproducción; Ratas; Malatión; Citotoxicidad.

\section{REFERENCES}

Agency for toxic subtances and disease registry (ATSDR). Technical register for public health professionals. Atlanta, Georgia, ATSDR, 2000.

Akbarsha, M. A.; Latha, P. N. \& Murugaian, P. Retention of cytoplasmatic droplet by rat cauda epididymal spermatozoa after treatment with cytotoxic and xenobiotic agents. J. Reprod. Fertil., 120(2):385-90, 2000.

Bello-Ramírez, M.; Carreón-Garabito, B. Y. \& Nava-Ocampo, A. A. A theoretical approach to the mechanism of biological oxidation of organophosphorus pesticides. Toxicology, 149(23):63-8, 2000.

Blazak, W. F.; Ernst, T. L. \& Stewart, B. E. Potential indicators of reproductive toxicity: Testicular sperm production and epididymal sperm number, transit time, and motility in Fischer 344 rats. Fundam. Appl. Toxicol., 5(6 Pt. 1):1097-103, 1985.

Bustos-Obregón, E. \& Hartley, B. R. Ecotoxicology and testicular damage (Environmental chemical pollution). A review. Int. J. Morphol., 26(4):833-40, 2008.

Chapman, J. C. \& Michael, S. D. Proposed mechanism for sperm chromatin condensation/decondensation in the male rat. Reprod. Biol. Endocrinol., 1:20, 2003.
Contreras, H. R.; Paredes, V.; Urquieta, B.; Del Valle, L. \& Bustos-Obregón, E. Testosterone production and spermatogenic damage induced by organophosphorate pesticides. Biocell, 30(3):423-9, 2006.

El-Mazoudy, R. H. \& Attia, A. A. Endocrine-disrupting and cytotoxic potential of anticholinesterase insecticide, diazinon in reproductive toxicity of male mice. J. Hazard. Mater., 209210:111-20, 2012.

Environmental Protection Agency (EPA). Pesticide News story: The EPA publishes amended Azinphos-Methyl cancellation order allowing use of existing stocks through September 2013. 2012. Available in: www.epa.gov/pesticides/chemicalsearch/

Espinoza-Navarro, O. \& Bustos-Obregón, E. Effects of malathion on the male reproductive organs of earthworms, Eisenia foetida. Asian J. Androl., 7(1):97-101, 2005.

Evenson, D. P.; Larson, K. L. \& Jost, L. K. Sperm chromatin structure assay: Its clinical use for detecting sperm DNA fragmentation in male infertility and comparisons with other techniques. J. Androl., 23(1):25-43, 2002.

Hossain, F.; Ali, O.; D`Souza, U. J. \& Ning, D. K. Effects of 
pesticide use on semen quality among farmers in rural areas of Sabah, Malaysia. J. Occup. Health, 52(6):353-60, 2010.

Jorsaraei, S.; Firoozjaee, A.; Pasha, Y.; Marzony, E. \& Sarabi, E. Histopathological effects of single dose treatment of diazinon on testes structure in rat. Yakhteh Med. J., 12(1):39-42, 2010.

Joshi, S. C. \& Sharma, P. Male reproductive toxicity of organophosphorous compounds: A review. Toxicol. Environ. Chem., 93(7):1486-507, 2011.

Kalipci, E.; Ozdemir, C.; Oztas, F. \& Sahinkaya, S. Ecotoxicological effects of methyl parathion on living thing and environment. African J. Agricul. Res., 5(8):712-8, 2010.

Kwong, T. C. Organophosphate pesticides: Biochemistry and clinical toxicology. Ther. Drug Monit., 24(1):144-9, 2002.

Lu, X. T.; Ma, Y.; Wang, C.; Zhang, X. F.; Jin, Q. \& Huang, C. J. Cytotoxicity and DNA damage of five organophosphorus pesticides mediated by oxidative stress in PC12 cells and protection by vitamin E. J. Environ. Sci. Health B, 47(5):445$54,2012$.

Mathur, P. P. \& D`Cruz, S. C. The effect of environmental contaminants on testicular function. Asian J. Androl., 13(4):585-91, 2011.

Narayana, K.; Prashanthi, N.; Nayanatara, A.; Bairy, L. K. \& D`Souza, U. An organophosphate insecticide methyl parathion (o- o- dimethyl o-4-nitrophenyl phosphorothioate) induces cytotoxic damage and tubular atrophy in the testis despite elevated testosterone level in the rat. J. Toxicol. Sci., 31(3):177189, 2006.

Okamura, A.; Kamijima, M.; Ohtani, K.; Yamanoshita, O.; Nakamura, D.; Ito, Y.; Miyata, M.; Ueyama, J.; Suzuki, T.; Imai, R.; Takagi, K. \& Nakajima, T. Broken sperm, cytoplasmatic droplets and reduced sperm motility are the principal markers of decrease sperm quality due to organophosphorous pesticide in rats. J. Occup. Health, 51(6):478-87, 2009

Penna-Videau, S.; Bustos-Obregón, E.; Cermeño-Vivas, J. \& Chirino, D. Malathion affects spermatogenic proliferation in mouse. Int. J. Morphol., 30(4):1399-407, 2012.

Yucra, S.; Rubio, J.; Gasco, M.; Gonzales, C.; Steenland, K. \& Gonzales, G. F. Semen quality and reproductive sex hormone levels in Peruvian pesticide sprayers. Int. J. Occup. Environ. Health, 12(4):355-61, 2006.

\author{
Correspondence to: \\ Prof. Dr. Omar Espinoza Navarro \\ Faculty of Sciences, Department of Biology \\ Universidad de Tarapacá \\ Av General Velásquez Nº 1775, Arica \\ CHILE
}

Phone: 56582205415

Fax: 56582205381.

Email: oespinoz@uta.cl

Received: 29-08-2013

Accepted: 13-12-2013 